\title{
Gaining relational competitive advantages: a conceptual framework on rent generation and appropriation
}

\author{
Yimei Hu \\ Department of Business and Management, \\ Aalborg University, \\ Fibigerstræde 10, Aalborg East 9220, Denmark \\ Email: yimei@business.aau.dk
}

\section{Si Zhang*}

Management School, University of Chinese Academy of Sciences, No. 80, Zhongguancun East Road,

Beijing 100190, China

Email: zhangsi@ucas.ac.cn

*Corresponding author

\section{Jizhen Li}

Research Center for Technological Innovation, School of Economics and Management,

Tsinghua University,

Beijing 100084, China

Email: lijzh@sem.tsinghua.edu.cn

\section{Olav Jull Sørensen}

Department of Business and Management, Aalborg University, Fibigerstræde 10, Aalborg East 9220, Denmark Email: ojs@business.aau.dk

\begin{abstract}
Establishing Strategic Technological Partnerships (STPs) with foreign partners is an increasingly studied topic within the innovation management literature. Partnering firms can jointly create sources of relational competitive advantage. Chinese firms often lack Research and Development (R\&D) capabilities but are increasingly becoming preferred technological partners for transnational corporations. We investigate an STP between a Scandinavian and a Chinese firm and try to explore how to gain relational competitive advantage by focusing on its two essential stages: relational rent generation and appropriation. Based on an exploratory case study, we develop a conceptual framework that consists of process, organisational alliance factors and coordination modes that we propose lead to relational competitive advantage.
\end{abstract}


Keywords: relational competitive advantage; relational rent; strategic technological partnerships; international management.

Reference to this paper should be made as follows: Hu, Y., Zhang, S., Li, J. and Sørensen, O.J. (2015) 'Gaining relational competitive advantages: a conceptual framework on rent generation and appropriation', European J. International Management, Vol. 9, No. 5, pp.566-592.

Biographical notes: Yimei Hu is an Assistant Professor in the Department of Business and Management, Aalborg University, Denmark. Her research focuses on global innovation management and organisation studies. She got her $\mathrm{PhD}$ in International Business Economics from Aalborg University and Master in Science and Technology Studies from Tsinghua University.

Si Zhang is an Assistant Professor in the Management School of University of Chinese Academy of Sciences. She graduated from Reading University in England and worked as a Postdoctoral Researcher at the Research Center for Technological Innovation and School of Economics and Management in Tsinghua University in China. She has cultivated profound interests and a good body of knowledge in the areas of globalisation and innovation management.

Jizhen Li is an Associate Professor in School of Economics and Management, Tsinghua University. He holds a PhD (2002) in Management Science, an MA in Management Science and BE (1997) in Automobile Engineering and Industrial Engineering, both from Tsinghua University. He visited the MIT Sloan School of Management as an International Faculty Fellow in 2006. $\mathrm{He}$ is also a Research Fellow and Vice Director at the Research Center for Technological Innovation at Tsinghua University. His research interests include management of technological innovation, science and technology policy and project management.

Olav Jull Sørensen is a Professor of International Business at the International Business Centre (IBC), established 1984, Department of Business and Management, Aalborg University. His major research interests are internationalisation of companies, global industrial dynamics and global value chains, and government-business relations. Since 2010, he has been serving as the Head of the Innovation Management programme under the Sino-Danish Center (SDC), Beijing.

\section{Introduction}

A Strategic Technological Partnership (STP) is a cooperative technological arrangement between two or more firms aiming to improve their performances and competitive market advantages through technology-based resource sharing and joint innovation activities (Das and Teng, 2000; Hagedoorn, 2002; Ireland et al., 2002; Jarillo, 1988). Over the years, STPs and international STPs have become increasingly popular (Hagedoorn, 1993; Narula and Hagedoorn, 1999; Yasuda, 2005). A few researchers have investigated the origins of new sources of competitive advantage from STPs, and suggest that firms can generate relational or inter-organisational competitive advantage through relational rent jointly created with other firms (Dyer and Singh, 1998). Though some determinants of relational rent generation have been preliminarily conceptualised (Dyer 
and Singh, 1998; Lavie, 2006), existing theories on this topic are far from sufficient. In particular, we argue that the procedure in which relational competitive advantage is generated within an STP has scarcely been investigated.

By means of an explorative case study, the aim of this study, i.e. to understand the generation of relational competitive advantages, is investigated by focusing on the two essential stages: relational rent generation and relational rent appropriation. The STP is between a Transnational Corporation (TNC) from Denmark and a firm in China. Hence, the case represents the STP between a developed and an emerging economy. As over $90 \%$ of companies on the list of the Times Global 500 have R\&D facilities in China, the case will clearly be of interest to TNCs and their subsidiaries. Firms in the developed world have noticed China's potential, not only because of its impressive market size, but also because of its technological development at both the national and firm levels (von Zedtwitz, 2004). It is therefore believed that this study can provide valuable implications for foreign investors seeking technological partnerships in China in the future.

The paper is organised as follows. Theories and concepts related to relational competitive advantage and STP are reviewed. This discussion is followed by an outline of the research methods used in this study and the presentation of the case information. Thereafter, we summarise findings from the case and propose a conceptual framework consisting of coordination modes and organisational alliance factors influencing the two key stages of relational competitive advantage generation, i.e. relational rent generation and appropriation. Finally, we present conclusions from our case study.

\section{Theoretical background}

Our research on relational competitive advantage is informed by two streams of research: (1) literature on STPs and R\&D strategic alliances and (2) the emerging literature on the conceptualisation of relational competitive advantage and relational rent.

\subsection{Strategic technological partnerships}

From a resource-based viewpoint, the basic motivation for strategic partnerships is the value-creation potential of firm resources that are pooled together, rather than transaction cost minimisation (Yasuda, 2005). Critical resources, especially knowledge required to product innovation, may be located beyond a firm's boundaries. Thus, one way to access such resources is to establish a technological partnership, which requires firms to adopt a cooperative R\&D strategy (Håkansson and Snehota, 1989). Many quantitative studies have shown that STPs, especially international STPs that involve TNCs, are becoming a popular arrangement for firms' R\&D needs, and are positively related to innovation performance and output (Cantwell and Janne, 1999; Hagedoorn and Narula, 1996; Yasuda, 2005; Zhang et al., 2007). Among international STPs, firms from emerging economies such as China are becoming particularly important partners, and TNC investors have been found to be in favour of STPs as an entry mode penetrating an unfamiliar market (Zhang et al., 2007). Yet many scholars have identified a high rate of failure in strategic partnerships due to opportunistic behaviours, task complexity, cultural and national differences, rivalry between partners and the inability to adapt to highvelocity environments (Duysters et al., 1999; Hamel, 1991; McCutchen et al., 2008; Wu, 2012; Park and Ungson, 1997), which has made the successful management of strategic partnerships a popular research topic. 


\subsection{Competitive advantage, relational competitive advantage and relational rent}

Seeking the sources of competitive advantage is a major research topic within the strategic management domain. From an industrial point of view, a firm's competitive advantage and position are influenced by its external competitive environment. The resource-based viewpoint argues that a firm's competitive advantage comes from its resource base, which is composed of valuable, rare, inimitable and non-substitutable resources (Barney, 1991; Peteraf, 1993). One commonality of these two viewpoints is that they both focus on the focal/individual firm level.

Though the two viewpoints described above have contributed to our understanding of how individual firms gain abnormal profits/returns, they neglect the fact that the creation of a focal firm's sources of competitive advantage is always connected to partnering firms' contributions. Unlike arm's length market transactions, which are neither idiosyncratic nor rare, a long-term and trustful relationship between partnering firms is a unique and inimitable arrangement that adds barriers for outsiders to gain access to shared resources and facilitates the creation of competitive resources on a relational or network level (Gomes-Casseres, 2003; Ireland et al., 2002). Therefore, as an emerging branch of strategic management, the relational viewpoint focuses on the dyadic or network level, and argues that sources of competitive advantage are often deeply embedded within networks of firms and that competitive advantages are gained from the creation of relational rent (Dyer and Singh, 1998; Duschek, 2004; Lavie, 2006). Relational rent is defined by existing literature as profit jointly generated by allied firms that derives from specific resources and assets that firms have jointly dedicated to the alliance and from the integration and exchange of member firms' resources (Durant et al., 2008; Dyer and Singh, 1998; Lavie, 2006; Mursitama, 2006).

A set of determinants regarding relational rent generation have been conceptualised and proposed, though research in this area is still limited. For example, Dyer and Singh (1998) conceptualise that relational rent generation has four determinants. Firstly, relational rent generation requires that member firms have complementary assets/ resources (Dyer and Singh, 1998; Mursitama, 2006). Secondly, relation-specific assets, which refers to assets that "are specialized in conjunction with the assets with an alliance partner" (Dyer and Singh, 1998, pp.662), are the condition for relational rent generation. Relation-specific rent mainly refers to physical and financial assets. Thirdly, an inter-firm knowledge-sharing routine, which is defined as a "regular pattern of interfirm interactions that permits the transfer, recombination, or creation of specialized knowledge" (Dyer and Singh, 1998, p.665), needs to be developed to ensure inter-organisational learning. Fourthly, effective governance is required for relational rent generation. However, this framework is still conceptual, linear and less than systematic.

Instead of relational rent generation, some scholars focus on the other side of the story, i.e. relational rent appropriation. For example, Lavie (2006) proposes that relational rent appropriation is influenced by the focal firm's absorptive capacity, opportunistic behaviours and bargaining power. Similarly, Dyer et al. (2008) propose that occupying an information-rich position as well as acquiring key information from such a position can improve a focal firm's relational rent appropriation. Capaldo and Petruzzelli (2011) prove that the greater the extent to which firms in an alliance search across different knowledge domains, the more relational rent is appropriated. In this study, we 
argue that to yield a competitive advantage through inter-organisational collaboration, relational rent must not only be generated, but also be appropriated by alliance firms, meaning that both stages are crucial.

In summary, several gaps in the extant research on relational competitive advantage were identified. Firstly, research in this area is mostly conceptual. In-depth case studies are rare, as is research on generating relational competitive advantages from STPs between developed and developing-country firms, leaving the crucial determinants of relational competitive advantage gained from STPs underdeveloped. Secondly, core concepts such as relational rent are still largely ambiguous. For example, relational rent is usually defined simply as abnormal economic profit. But, in practice, it is also used to describe tacit gains. Thus, the definition needs to be refined. Thirdly, we question the accuracy of the portrayal of the generation of relational rent as equal to the creation of relational competitive advantage. We argue that both relational rent generation and appropriation are crucial to gaining relational competitive advantage. Yet the existing literature lacks a process-based perspective on understanding how relational competitive advantage is secured by incorporating rent generation and rent appropriation into a dynamic system.

\section{Research methods}

Based on existing theoretical development and current research gaps, our research objective is to further our knowledge of relational competitive advantage by focusing on relational rent generation and appropriation through STPs on a dyadic (relational) level. Therefore, in order to explore how relational competitive advantages are achieved through STPs, the following two research questions are proposed: (1) what are the key elements that have impacts on the two essential stages of rent generation and appropriation within an STP? (2) How do those elements coordinate together in the mechanism that produces relational competitive advantages for both parties in the STP? The first question corresponds to the gap created by the lack of studies of creating relational competitive advantage from STPs and the integration of relational rent generation and appropriation, while the second research question addresses our desire to outline a systematic framework for relational competitive advantages.

Owing to the theory building and expanding nature of this study, this paper employs an explorative case strategy (Dyer and Wilkins, 1991; Eisenhardt, 1989; Siggelkow, 2007; Yin, 2008). We investigate an STP between Circular, a Danish TNC, and Sunshine, a Chinese solar corporation. ${ }^{1}$ Some may question the persuasiveness of a single case study. Yin (2008) states that multiple case studies in general are more convincing than a single case study. However, other scholars have argued that even a single case study can be a very powerful tool for theory building (Dyer and Wilkins, 1991; Eisenhardt and Graebner, 2007; Siggelkow, 2007). As cases should be special in some way, it may not be easy to find multiple suitable cases, especially when the purpose of the study is theory building.

As regards this study, on the one hand, the chosen case clearly shows how partnering firms jointly create relational rent and then ensure appropriation from an STP. On the other hand, this case shows a unique situation in which the Chinese firm acts as an important R\&D partner rather than solely being in charge of marketing or governmental relations locally, as is the common arrangement. Table 1 provides some 
basic information on the two companies. There is fierce competition in the Chinese solar thermal industry, with more than three thousand solar heater brands on the market. However, since many companies suffer from a lack of core technology, they have to compete in the price war of low-end markets. Therefore, as a leading company that holds core technology, Sunshine hopes to establish a positive and reliable brand image so as to gain competitive advantage. As the world's largest manufacturer of pump circulators, Circular established its Chinese subsidiary in 1994 and regards China as its second-home market. Now Circular has more than 1600 employees in China and has annual sales of more than 1.5 billion RMB, which shows that it has gained a strong foothold in the Chinese market.

Table 1 Basic information on case companies

\begin{tabular}{lll}
\hline & \multicolumn{1}{c}{ Circular } & \multicolumn{1}{c}{ Sunshine } \\
\hline Size (employees) & $\begin{array}{l}\text { Around 17,500 globally, around 1700 } \\
\text { in China including around 200 R\&D } \\
\text { employees }\end{array}$ & Around 5000 \\
\hline Industry & Pump & Solar energy \\
\hline Age & $\begin{array}{l}\text { Founded in 1945. Chinese subsidiary } \\
\text { established in 1994. }\end{array}$ & Founded in 1996 \\
\hline Market share & $\begin{array}{l}\text { One of the world's largest pump } \\
\text { manufacturers, encompassing 50\% } \\
\text { of the global market share for circulator } \\
\text { pumps, with a turnover of 3025 million } \\
\text { euros in 2012. }\end{array}$ & $\begin{array}{l}\text { No. 1 in China, owning several } \\
\text { brands aimed at different segments } \\
\text { manufacturer of solar panels and solar } \\
\text { heating units. }\end{array}$ \\
\hline Global footprint & $\begin{array}{l}\text { Headquarters in Denmark. Represented } \\
\text { by more than 80 companies in more } \\
\text { than 55 countries. }\end{array}$ & $\begin{array}{l}\text { Located in Shandong province, } \\
\text { China. Targeting not only the } \\
\text { Chinese market, but also the }\end{array}$ \\
& $\begin{array}{l}\text { European and North American } \\
\text { markets. }\end{array}$ \\
\hline $\begin{array}{l}\text { Technological leading technology on pumps } \\
\text { and pump systems. The Chinese R\&D } \\
\text { centre is the largest centre, except for } \\
\text { the R\&D done at the Danish } \\
\text { headquarters. }\end{array}$ & $\begin{array}{l}\text { Owns the world's biggest solar energy } \\
\text { test centre. More than 600 national } \\
\text { patents and around 132 national } \\
\text { science and technology projects. }\end{array}$ \\
\hline
\end{tabular}

Both primary interview data and secondary data are collected. As our objective is to explore new insights from the case, we carried out semi-structured interviews, which allowed the interviewees to discuss both the facts of the case and their own insights into the partnership. The interviews were conducted in three forms: face-to-face, telephone and email. We identified three types of key informants, R\&D and commercial directors, project managers (both technical and business managers) and project members (engineers) from both companies, and carried out several rounds of interviews between October 2011 and February 2014.

In October 2011, we had a general discussion with one R\&D director from Circular, and got to know about this partnership and some general information on partner selection and strategic consideration. After that, we decided to study this STP, and therefore spent one week interviewing and observing at both companies, and we collected data on how they collaborate on $R \& D$, coordinate the partnership and generate rent from it. In the marketing stage, we collected data on how the member firms do marketing together and 
distribute rent. After composing the preliminary conceptual framework, we let some interviewees reflect on the case and check the framework we had created. It is worth noting that though our research is only focused on the partnership between Circular and Sunshine, we collected general data related to the two companies' R\&D strategy, organisation and innovation management in order to understand the case better. Most interviews were recorded and transcribed. In addition to collecting data through interviews, we also gathered data through our observations while visiting the companies, where we paid special attention to the joint laboratory. We made reflective records during and after interviews and observations. The total time spent in interviews and discussions was approximately 29 hours.

Secondary data are mainly from the firms' annual reports, internal magazines and websites. We studied ten years' worth of Circular's annual reports, Sunshine's internal magazines and its CEO's blogs. In addition, secondary data such as media interviews and reports were collected from reliable sources. These secondary data provide us with rich foundational knowledge of the two companies' histories, strategies, organisations and corporate cultures. Triangulating data from different sources allowed us to cross-check the validity of the information given by interviewees (Yin, 2008), and different sources of evidence were found to support our framework.

The data analysis for this study followed a typical coding process (Glaser and Strauss, 1967; Miles and Huberman, 1994). We first open coded our primary and secondary data into 123 nodes. Then, through axial coding, which is a procedure for connecting different themes, those themes that are related to relational rent generation and appropriation were selected. We also looked into the relationships among selected themes, reflected on existing theories and constructed a conceptual framework showing how these factors are related to relational competitive advantages. The preliminary framework was shown to some interviewees to check the validity, and after several rounds of revision and discussion, we came up with the final framework presented in this paper.

\section{Two giants holding hands: a strategic technological partnership between the 'solar king' and the 'pump king'}

\subsection{Partnership formation: start from scratch}

As early as 2009, Circular had recognised the market potential of the solar industry and considered tapping into the solar market by collaborating with Chinese solar companies. After having investigated Chinese solar companies carefully, Circular regarded Sunshine as a potential partner. The partnership started with informal communication between a technical manager from Circular and the technology director from Sunshine, whom Circular recognised as 'key personnel' - someone who could influence Sunshine's decision-maker, i.e. its founder and CEO.

There was no clear definition of the objectives of the collaboration between the two companies, and they did not have a blueprint for what products they would jointly develop at this initial stage. Given an assessment of the Chinese solar heater market jointly, Sunshine and Circular noticed a gap. Most solar heaters in the Chinese market are designed to work without pumps or are equipped with non-pressurised, constant-speed pumps. Thus, these solar heaters cannot consistently provide users, especially those 
living in tall buildings, with comfortable water conditions due to insufficient water pressure. Another problem with most constant-speed pumps is wasted energy. This energy loss is significant, though often overlooked by consumers. As described by a commercial director from Circular: "These systems (the current solar heating systems selling in China) don't provide much a lot of comfort. They are very limiting in specifications on how much hot water I can get, where I can bring the hot water, and how reliable it is. When I want to use the hot water, how long does it take before I get it?"

The two representatives, i.e. the technical manager from Circular and the director from Sunshine, envisioned and discussed the potential for developing something 'groundbreaking' by combining both companies' R\&D specialties, i.e. integrating Circular's 'E-pump' with Sunshine's solar thermal system. The 'E-pump' is a variable and intelligent pump that can adjust its speed according to current water temperature and pressure, which can save a substantial amount of energy. After several informal meetings between the two representatives had taken place, this interpersonal communication led to executive-level visits, and formal firm-level communication and negotiations were initiated. Both firms could envision significant market potential for new products, which further enhanced their confidence in the collaboration. The two firms carried out some trials together in order to ensure that the idea of jointly developing a new product was viable. After three to four months of discussions and trials, Sunshine and Circular clarified the concept for a new-generation solar heating system and concepts for subsequent products they sought to create. The means of collaboration, i.e. Circular as an OEM pump designer and supplier to Sunshine, was also determined.

Both firms' strategies were taken into consideration when forming the STP. From Sunshine's perspective, since in-depth knowledge in pump technology is crucial to developing new products, Circular, the 'pump king', is undoubtedly the best partnership candidate, given that its knowledge base is a vital complement to Sunshine's. In addition, Sunshine and Circular are both highly reputable brands in their corresponding industries and have world-leading technological resources as well as well-developed sales networks, which allow the two firms to benefit from each other's brand influences. Thus, this collaboration allows the two parties to share equal status in the partnership and avoids situations in which one partner dominates the other. The project manager from Circular used the following simile: "Collaboration is like marriage, we have to match. Though it is still possible to collaborate when the two parties have great differences in status and capability, the process will be very tough."

Meanwhile the two firms' corporate values are in line with each other; i.e. both firms pursue innovation, sustainability and green strategies. This precludes some possible conflicts caused by distinct corporate values and strategies. For example, many Chinese companies have earned huge profits from the emergence of the photovoltaic industry in the past few years. However, Sunshine never entered the photovoltaic market, even though it has the technological and economic capabilities to do so, because its founder and CEO realised that the terrible pollution that the production of photovoltaic products could potentially cause would contravene Sunshine's corporate values.

Furthermore, a technological partnership matches the current strategic agendas of both firms. Prior to the formation of the partnership, Circular had faced challenges from its competitors with better market positions and brand influence in China, so it sought to enhance its competitive position through developing its business in the solar industry and had begun investigating potential partners. As the largest global manufacturer of solar panels and solar units, and facing fierce competition from Chinese rivals, Sunshine 
devised a strategy several years ago to target the high-end market in order to stabilise its market share and enhance its brand reputation. As mentioned above, the previous generation of solar water heaters cannot consistently provide stable water pressure and temperature. Sunshine was aware of the increasing comfort demands of users and believed there was market potential for developing a new generation system by introducing world-leading pump technologies. Thus, the two companies are strategically important to each other, and this strengthened their interdependence.

Finally, unlike many firms pursuing a diversification strategy or cross-industry development, both companies in this STP tend to focus on their own specialisations, even though their joint R\&D provides opportunities for both firms to learn about each other's technological know-how. This fact somewhat reduced the companies' worries about the possibility of becoming competitors in the future. Sunshine's project manager explained: "Though we share knowledge, it doesn't mean that Circular will produce solar heaters and Sunshine will produce pumps. Plus, there is a large amount of tacit knowledge and know-hows in each industry, so it is hard to fully understand in a short time."

Similarly, a commercial director from Circular said: "Circular is a pump supplier, we are not a solar thermal producer. Some guys in our company think we can be, but we will never ever be that, because it's a complete different business, especially in China. It would make no sense to say, let's start competing with Sunshine."

Moreover, they are well aware of the organisational differences between them in terms of corporate culture, management style, evaluation system, employees' educational backgrounds and English skills, etc. Possible conflicts were also considered when designing the collaboration contract and agreement.

\subsection{Joint $R \& D$ : a new solar system}

After the companies recognised each other as the most suitable potential partner, the STP was finally commenced in September 2010.

They jointly established a state-of-the-art research centre to support their R\&D activities. Sometimes such joint labs are joint in name only or are created merely for prestige, lacking real resource commitment from one or both parties. But since the project in this case was not simply adding a pump on top of a water tank, strategic resources from both sides were invested in the partnership, e.g. some experimental devices. Sunshine was responsible for investing in solar heating-related experimental devices, while Circular donated pump-related facilities. A project team was formed, consisting of around 20 engineers and experienced R\&D managers from both companies. Regarding Circular, both Danish engineers from the headquarters and Chinese engineers from the Chinese R\&D subsidiary were included in the project. Additionally, one project manager from Sunshine and two managers (one technical manager and one commercial manager) from Circular were assigned to communicate and work together. Considering it is a joint $R \& D$ project, both firms spared no efforts, and any knowledge that was related to the R\&D of the new products was open to the partners. Such an open attitude not only reduced potential obstacles during the R\&D process, but also enhanced the trustful relationship between engineers and the two companies.

Circular and Sunshine co-created a transparent and cooperative knowledge-sharing routine which encouraged project members to work and communicate with each other on a regular basis. As a TNC with more advanced R\&D management experiences and know-how, Circular was also able to share this knowledge with Sunshine during the 
collaboration. Executive-level meetings between the two firms were held on a monthly basis. Engineers were allowed to work on-site in each other's labs. Whenever problems and task delays occurred, Circular and Sunshine proposed all possible solutions and tried to solve problems together. This helped solve problems more efficiently, minimise risks and enhance mutual trust because of the positive and open attitudes of both companies.

In the joint R\&D phase, differences between the two companies emerged. For example, in terms of flexibility, Sunshine reacted faster when changes were needed, while Circular had a longer response period due to its standardised management procedures. Another example of differences was that the two companies had different attitudes towards problems. Sunshine tended to end with problem-solving, while Circular tended to do more in-depth theoretical research when problems arise, aimed at finding the underlying reasons and future impacts of problems, which also resulted in a longer response period. A Circular manager stated: "When a technical problem occurs, Sunshine goes and finds a solution. However, Circular goes further by doing some analyses and finding out whether the solution will cause any future side effects and whether or not the solution can be used in the future when similar problems occur."

Moreover, Sunshine and Circular differ in their project management and evaluation systems. Therefore, they jointly designed an output-oriented mechanism to manage R\&D activities, which obviated the need to alter either firm's existing working style and evaluation system. Both signed detailed contracts and agreements establishing responsibilities, benefits and project schedules. They scheduled regular meeting mechanisms and reduced potential conflicts in order to ensure long-term collaboration. In this case, the trust between Circular and Sunshine played a significant role in encouraging transparent knowledge sharing and mutual learning, which complemented their contracts. As noted by Circular's project manager: "A contract cannot cover everything ... Based on the principle of mutual trust, we fully communicate with each other, and we keep the communication channels between us open and smooth."

In August 2012, their first jointly produced product became available on the market: a compact solar heating system. In contrast to previous products, which lacked an aesthetically pleasing shape and were complicated to install, the new system supports plug-and-play. More importantly, due to the integration of Circular's variable pump technology, the new solar heating system improves user experience and saves energy significantly.

\subsection{Post-product development}

Circular and Sunshine discussed the rent distribution carefully in order to ensure a mutually beneficial arrangement. Generally speaking, firms get both tangible and intangible fruitages from an STP.

This STP has resulted in technological advancements for both the solar heating and pump industries. The project encompasses a series of patent applications, and the research results are owned by both firms. The newly developed system has already been launched into the market, with promotion targeting both European and Chinese high-end markets. An annual growth rate of $30 \%$ is expected, corresponding to an approximate surge in profits of 4 million euros during the first three years. However, though both firms are confident about the market potential of the product, the sales for the first couple of months were not satisfactory, due in part to the downturn in the global solar industry and in part to Sunshine's overly optimistic projection. As explained by a commercial 
director from Circular: "We will have to wait five and ten years, basically the bet is not on Sunshine, the bet is whether the solar thermal industry is gonna be right. If you look at the latest news, they still think it is the right thing to do."

Regarding marketisation of the product, it was finally agreed by the two firms that Sunshine's sales networks should be used in order to avoid potential problems related to after-sales service. Circular assigned another business manager to facilitate marketing with Sunshine, and helped Sunshine with marketing. For example, the co-developed system is on display in Circular's concept store in Shanghai, though Sunshine should be taking care of the marketing as they agreed. As a result of both firms' efforts, sales have improved. Circular's manager honestly stated: "It would be a lie to say that the relation was not influenced at all, but in order to increase both companies' benefits, we are now working on marketing together, and we have seen some improvements."

Besides the economic and technological benefits, such as patents, both firms have also gained intangible benefits from the partnership.

One important dimension of intangible rent is related to brand influence. According to the agreement, the final product is owned by Sunshine, and Circular gets commissions. Only Sunshine's brand name appears on the newly developed solar heating system, which could be deemed nothing more special than an OEM model. However, because of the strategic importance of this partnership and based on the possibility of further longterm collaboration, the two companies considered adding both companies' brand names to the product. Yet as explained by a technical manager from Circular, the final decision of not to do so was based on mutual understanding:

"When discussing the product appearance, we considered and wanted to add both companies' names outside of the product, which will be 'Co-developed by Sunshine-Circular joint lab'. However, after careful discussion, we thought that this brand name may cause confusion to consumers when regarding after sales service, etc. Besides, according to the Chinese brand law, there can only be one name appear on the outside of a product. We decided to only use Sunshine's brand. Yet, Circular's brand name is shown inside of the solar system, which is also something rare to an OEM supplier."

This again proves the trustful relationship and the depth of the collaboration between the two companies. Despite its brand name not appearing on the product, Circular nevertheless improved its position and influence significantly in the Chinese market, especially within the solar industry, through this R\&D collaboration. As described by a commercial director, Circular is now a preferred partner for many more Chinese solar companies: "We went from a position where our main competitor had a stronger position than us in the solar thermal industry in China. That has been turned upside down now; everyone in the solar thermal industry wants to talk to us now, because they have seen what we have done and it is new."

This STP opened the door for Circular to understand the solar industry better and to gain experience in doing business in China, especially in R\&D collaboration with Chinese companies. As a Chinese company, Sunshine was able to learn advanced managerial techniques and world-leading R\&D standards from Circular, which can also lead to improvements in brand image.

The points discussed above show that both firms have improved their competitiveness through the STP. According to an R\&D director from Circular: "Despite the unsatisfactory issues, I still think the collaboration was a success." 
Moreover, this STP was recognised by the Danish and Chinese governments and was regarded as a successful model of CN-EU R\&D collaboration. The jointly developed research laboratory, the invested resources, the jointly created working style and the outcomes achieved thus far all provide a foundation for continuing the STP. When reflecting on the collaboration, both firms regard each other as a competent strategic partner and have positive expectations for strengthening this STP in the future. A technical manager from Sunshine stated: "When collaborating at this level, we are not simply customer-supplier relationship; rather we are strategic partners to each other."

Similarly, as a Circular manager explained, this partnership, and the level of depth at which the two companies have collaborated, have been perceived as unique and are likely never to be replicated: "Circular may also collaborate with other solar companies in the future on some development projects, but in terms of collaborating at such an in-depth level with such transparency in knowledge sharing as in this partnership with Sunshine, I can hardly believe there will be another case. I believe that the story between Circular and Sunshine will continue."

\section{Case findings and discussions}

In response to the two research questions proposed in Section 3, we will first clarify the concept of relational rent. This will be followed by a summary of key factors and related tasks regarding relational rent generation and appropriation based on the case. Then, a conceptual framework showing the systematic relationships between the key elements will be proposed.

\subsection{Revisiting relational rent}

Existing studies often define relational rent simply as the supernormal economic profit jointly created by member firms (Dyer and Singh, 1998; Lavie, 2006; Mursitama, 2006). Yet, we can see that the expected revenue is just one comparatively small part of the benefit that Circular and Sunshine enjoy from the STP, which takes the form of, for example, profit from new product sales and knowledge rent from selling codified knowledge and patents. Both partners also emphasise that they have gained more valuable inputs than simply revenue from their partners. These are, we believe, intangible rents. These intangible rents are valuable, but they are hard to put a price tag on. For instance, both companies acquired managerial capability, knowledge spillovers and improvements in brand awareness and market stance. Both tangible and intangible rents are sources of relational competitive advantage, since they are valuable resources that can hardly be replicated or imitated by another partnership.

Yet, if we reflect on the case, we may find that not all relational rent generated or appropriated by the two firms are intended, meaning that there may be unexpected relational rent, especially in the context of an STP. Relational rent can therefore be categorised into four types, as shown in Figure 1. The intended tangible and intangible relational rent (Box A and B) are discussed above. 
Figure 1 Relational rent in an STP

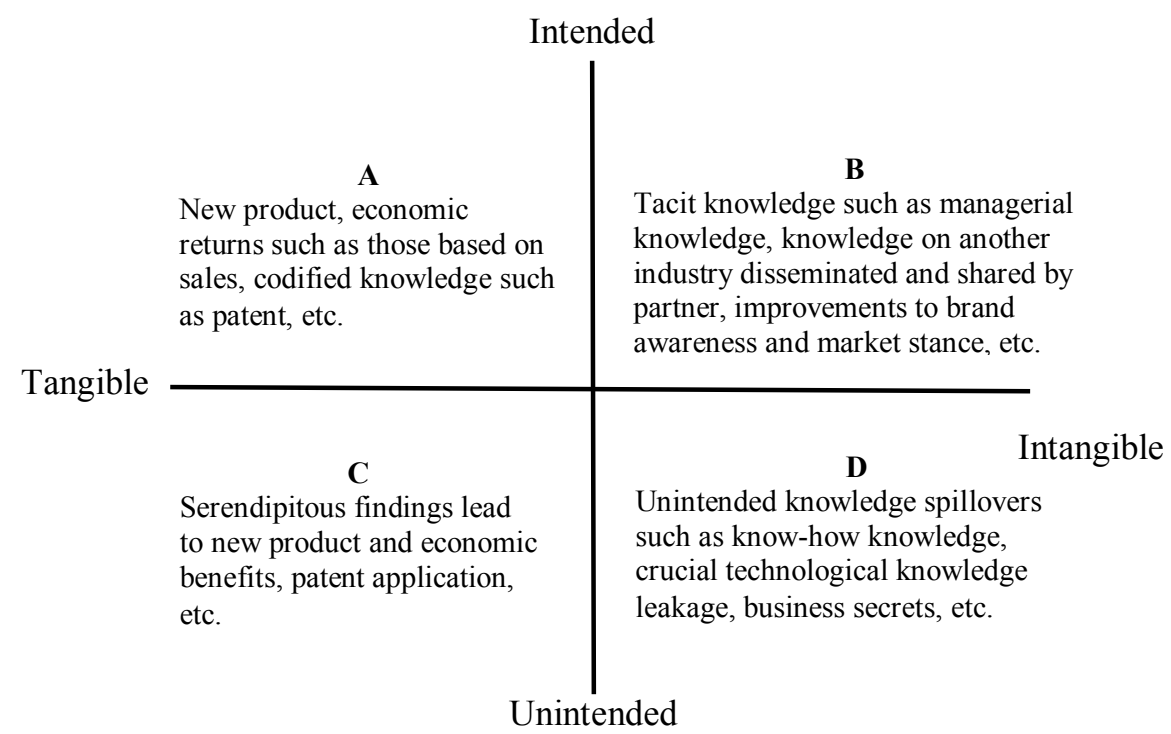

We can also find hints indicating unintended rent from the case, though these are less obvious. During the R\&D process, the two companies gained new knowledge that exceeded existing academic research (see illustrative quotes in Table 2). In an extreme case, such serendipitous findings may lead the STP in a new direction, meaning that the STP may end up developing a new product different from the original plan. Along with the 'unintended' new product, codified knowledge such as patents may also be generated and appropriated (see Box C in Figure 1).

An unintended intangible rent mainly refers to knowledge spillovers (Box D in Figure 1). Usually, knowledge spillovers are knowledge unintentionally transferred or leaked to a partner beyond the boundaries of a focal firm or a contract. The acquisition of unintended knowledge spillovers is determined by a firm's absorptive capacity (Cohen and Levinthal, 1990). With an open knowledge sharing environment, Sunshine and Circular shared knowledge that exceeded the product level, and both parties learned significantly from each other based on observation and communication. Such knowledge transfer is usually done unconsciously on the part of both partnering firms. For example, Circular gained experience with collaborating with Chinese partners and a more in-depth understanding of the Chinese solar market.

\subsection{Relational rent generation}

To answer our research question "What elements are essential to relational rent generation?" through the analysis of the case, we identify four key issues that facilitate relational rent generation, as shown in Table 2: finding the right partner, resource commitment, knowledge creation and effective coordination. 
Table 2 Key factors and tasks of relational rent generation: Illustrative quotes

\begin{tabular}{|c|c|c|c|}
\hline Stage & Key issues & & Tasks and illustrative quotes \\
\hline \multirow{16}{*}{$\begin{array}{l}\text { Relational } \\
\text { rent } \\
\text { generation }\end{array}$} & \multirow{16}{*}{$\begin{array}{l}\text { Find the } \\
\text { fit partner }\end{array}$} & \multicolumn{2}{|l|}{ Fit } \\
\hline & & \multicolumn{2}{|r|}{$\begin{array}{l}\text { Resource endowment fit: complementary and supplementary } \\
\text { "Circular and Sunshine are both leading companies in our } \\
\text { respective industries." }\end{array}$} \\
\hline & & \multicolumn{2}{|r|}{$\begin{array}{l}\text { "Though Circular as a brand is not known by normal } \\
\text { consumers, but in the pump industry, it is a well-known leading } \\
\text { brand that is familiar to costumers and professionals. Sunshine } \\
\text { is a household name in China. After all, one brand feeds the } \\
\text { other." }\end{array}$} \\
\hline & & \multicolumn{2}{|r|}{$\begin{array}{l}\text { "So if you don't have the system level competence in place, } \\
\text { you can't make this strategic partnership go on and have people } \\
\text { to do whatever." }\end{array}$} \\
\hline & & \multirow{2}{*}{\multicolumn{2}{|c|}{$\begin{array}{l}\text { "We draw help from each other's brand influences, and we } \\
\text { believe it's a win-win situation." } \\
\text { Strategic fit: strategic importance, common values and focus on } \\
\text { own specialties }\end{array}$}} \\
\hline & & & \\
\hline & & & Strategically important to each other \\
\hline & & & "We are strategic partners to each other." \\
\hline & & & $\begin{array}{l}\text { "We have our supply chain that finds our strategic partners } \\
\text { in China based on long-term relationships." }\end{array}$ \\
\hline & & & Common values \\
\hline & & & $\begin{array}{l}\text { "If you take a look at the two companies' values, you will } \\
\text { find them in line with each other." }\end{array}$ \\
\hline & & & $\begin{array}{l}\text { "For our descendants' clear sky, achieving energy } \\
\text { alternatives globally' ... we have similar sayings in } \\
\text { Circular." }\end{array}$ \\
\hline & & & Focus on own specialties \\
\hline & & & $\begin{array}{l}\text { "Two main technologies to utilize solar energy are solar } \\
\text { thermal and solar photovoltaics. Though the Chinese } \\
\text { photovoltaic companies made huge profits during the } \\
\text { past several years, the Sunshine has never stepped into the } \\
\text { production of photovoltaic products though they have the } \\
\text { capability. The CEO saw the huge environmental pollution } \\
\text { of production and regarded it as violating Sunshine's basic } \\
\text { value." }\end{array}$ \\
\hline & & & $\begin{array}{l}\text { "Circular is a pump supplier, we are not a solar thermal } \\
\text { producer ... It would make no sense to say, let's start } \\
\text { competing with Sunshine." }\end{array}$ \\
\hline & & & $\begin{array}{l}\text { "We had a customer called XX, they decided to do solar } \\
\text { panels themselves, including both solar panels and PV in } \\
\text { Portugal. They are pulling out China now, because the } \\
\text { competition is too tough and too much over capacity." }\end{array}$ \\
\hline
\end{tabular}


Table 2 Key factors and tasks of relational rent generation: Illustrative quotes (continued)

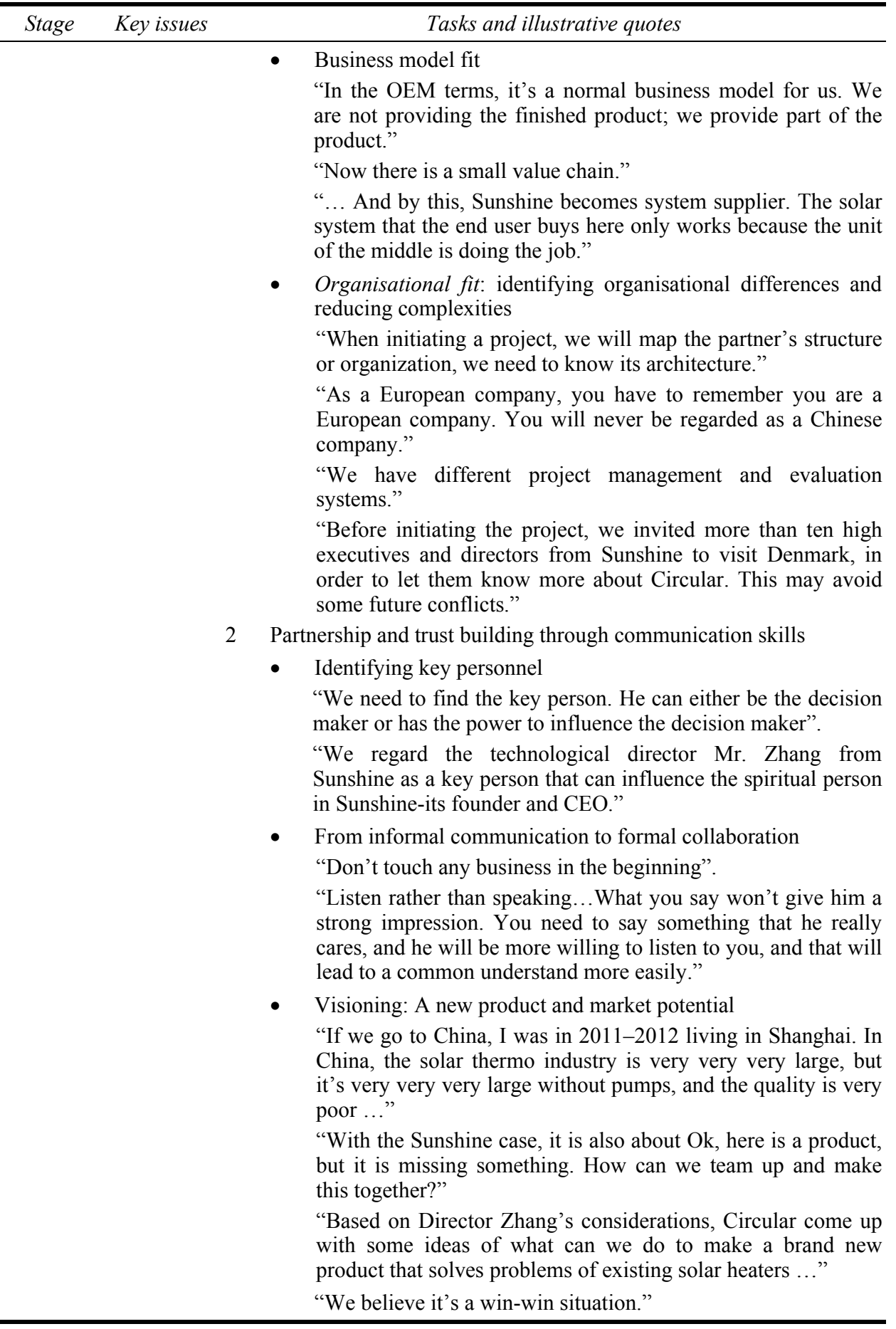


Table 2 Key factors and tasks of relational rent generation: Illustrative quotes (continued)

\begin{tabular}{|c|c|c|}
\hline Stage & Key issues & Tasks and illustrative quotes \\
\hline & \multirow{3}{*}{$\begin{array}{l}\text { Resource } \\
\text { commitment }\end{array}$} & $\begin{array}{l}\text { Allocating strategic resources: financial resources, technological and } \\
\text { knowledge resources, time and human resources }\end{array}$ \\
\hline & & $\begin{array}{l}\text { "A joint lab can mean nothing. We both decided to do something } \\
\text { practical. We have to do something to integrate the two } \\
\text { companies' capabilities." }\end{array}$ \\
\hline & & $\begin{array}{l}\text { "There is a real engineering development job coming from } \\
\text { a pump to a solar station that can run this one. That's } \\
\text { many hours." }\end{array}$ \\
\hline & \multirow{8}{*}{$\begin{array}{l}\text { Knowledge } \\
\text { creation }\end{array}$} & $\begin{array}{l}\text { Knowledge-sharing and mutual learning based on dissemination } \\
\text { capacity and absorptive capacity }\end{array}$ \\
\hline & & $\begin{array}{l}\text { "... but in terms of collaborating at such an in-depth level } \\
\text { with such transparency in knowledge sharing as in this } \\
\text { partnership with Sunshine, I can hardly believe there will } \\
\text { be another case." }\end{array}$ \\
\hline & & $\begin{array}{l}\text { "We shared a lot of things with Sunshine, although some } \\
\text { knowledge are not directly related to pumps ... we did a lot } \\
\text { of experiments and shared the results and data with Sunshine. } \\
\text { We actually found something interesting that exceeded } \\
\text { existing academic research results ..." }\end{array}$ \\
\hline & & $\begin{array}{l}\text { "Sunshine is willing to share some knowledge that exceeds the } \\
\text { current solar system and product line. Both parties learnt a lot } \\
\text { from this partnership." }\end{array}$ \\
\hline & & $\begin{array}{l}\text { "We don't worry much on so-called technology leakage or } \\
\text { spillover, after all it is solar knowledge. There are a lot of know- } \\
\text { hows. We grow together." }\end{array}$ \\
\hline & & $\begin{array}{l}\text { "We have to understand each other and grasp what they mean. } \\
\text { You have to understand what your partner is thinking about." }\end{array}$ \\
\hline & & $\begin{array}{l}\text { "It is something new we do ... it needs both sides' knowledge, } \\
\text { you know, we need the synergy." }\end{array}$ \\
\hline & & $\begin{array}{l}\text { "This brings us a lot of opportunities to win other customers ... } \\
\text { This project also tells us what new pumps is more suitable for } \\
\text { China market, since the market demand is different between EU } \\
\text { and China." }\end{array}$ \\
\hline & \multirow{3}{*}{$\begin{array}{l}\text { Effective } \\
\text { coordination } \\
\text { to avoid } \\
\text { learning } \\
\text { races }\end{array}$} & Eclectic solution \\
\hline & & $\begin{array}{l}\text { "We have a common goal, so all the efforts are towards the goal, } \\
\text { therefore there won't be too many variables during the process and } \\
\text { the coordination in general is not too difficult." }\end{array}$ \\
\hline & & $\begin{array}{l}\text { "We set up several milestones. When one milestone is achieved, } \\
\text { it can go though both Circular and Sunshine's process or project } \\
\text { management system." }\end{array}$ \\
\hline
\end{tabular}


Table 2 Key factors and tasks of relational rent generation: Illustrative quotes (continued)

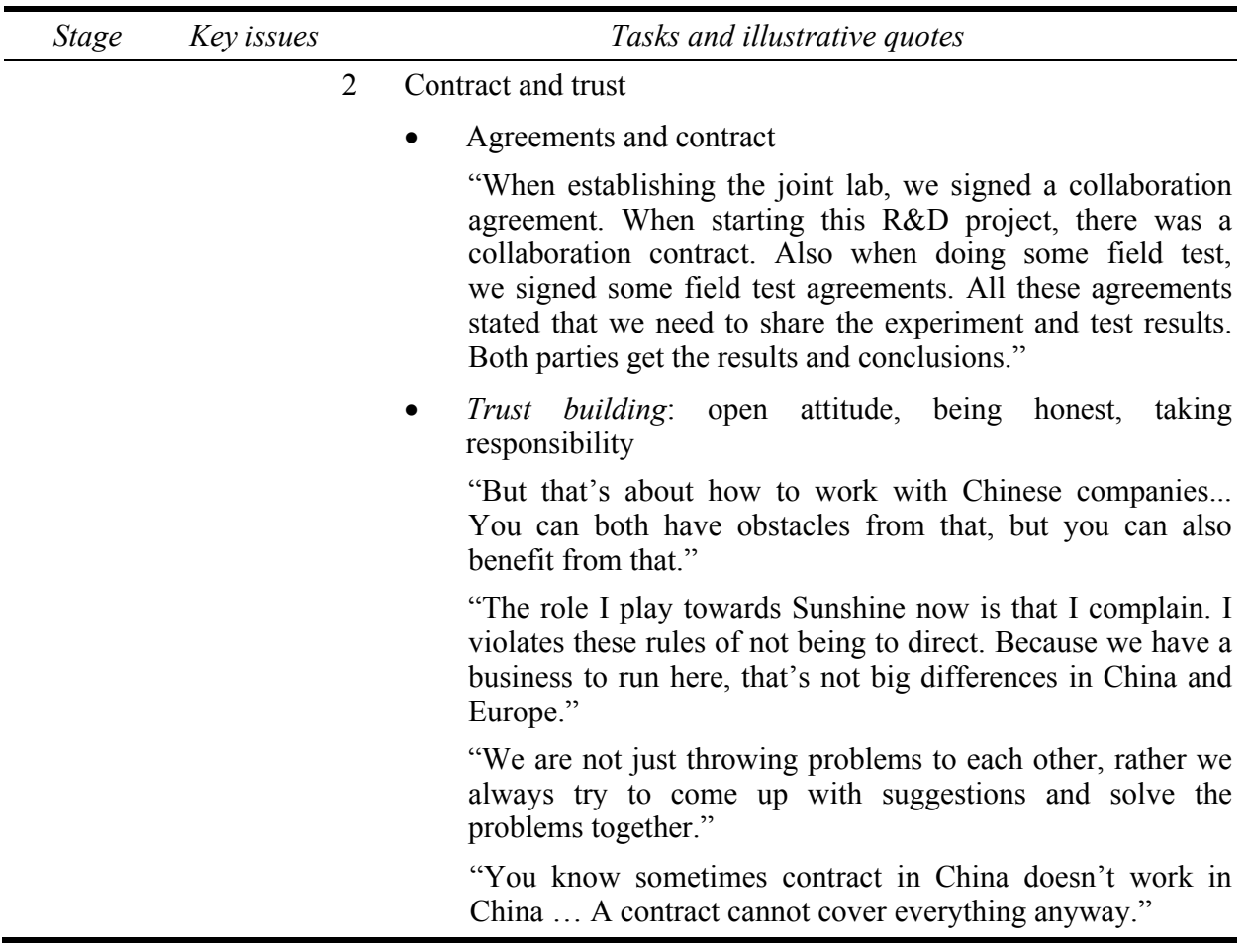

\subsubsection{Finding the right partner}

As explained in the existing literature, the success of a partnership starts with and often depends upon the degree of the firms' alignment, i.e. the fit between partners (Datta, 1991; Douma et al., 2000; Dyer et al., 2001; Kale and Singh, 2009). This case identifies resource endowment fit, strategy fit, business model fit and organisational fit to be the four different types of alignments that should be considered when initiating an STP, which are outlined below.

First of all, unlike most studies, which overemphasise the importance of complementary resources, this case argues that supplementary resources are also essential to an STP. In this case, complementary technological knowledge and experience from both the solar thermal and pump industries are needed, since neither firm can develop the new product alone. However, as emphasised by our interviewees, a partnership, especially an R\&D partnership, can hardly be successful if one party does not match the knowledge or financial strength of its partner, because the weaker party will be unable to comprehend its counterpart or accomplish the task. Since both parties in the case complement each other because of their influential brands and strong innovation capabilities, the possibility of a situation in which one member dominates is reduced. Thus, supplementary resources can ensure the fit between partnering firms.

Secondly, strategic fit determines the potential for collaboration based upon how well aligned each firm's strategic focus and vision are. Since Sunshine and Circular are very focused on their own specialised areas, rather than on pursuing diversification in different industries, the chances of entering their partner's business and becoming competitors in 
the future is reduced. Since many foreign companies are terrified of 'copycats' in China, strategic fit in terms of a focus on its own specialty as criteria for partner selection may be extremely valuable when initiating an STP with Chinese firms.

Thirdly, the two companies' business models are well matched. With Circular as an OEM supplier to Sunshine, potential conflicts on rent distribution and worries about becoming competitors in the future are reduced. Last but not least, the two companies identified organisational differences and possible conflicts before designing the agreement, which can reduce complexity and uncertainty before forming the partnership.

Applying communication skills to facilitate trust building is an important task when searching for fit partners. Identifying key personnel, initiating informal communication and visioning are three effective skills. Key personnel can either be the decision-makers themselves or a person who has the power to influence the decision-maker. The STP in this case started with informal communication, which attracted executive-level attention and then became formal, firm-level communication and negotiations. This illustrates a feature of doing business in the Chinese context: initiating informal communication first rather than going through official company-level contacts creates a foundation for a company-level partnership. If the interpersonal communication in this case had not been between key personnel, the STP might not have been realised. Visioning is about cultivating confidence and a positive anticipation in the partnership. At the initiation stage, market and technological uncertainties are very high, and firms are not sure whether they need an STP. By visioning the future through in-depth communication with the potential partner, both firms gain a clearer picture of how their collaboration would unfold. Moreover, by applying these communication skills, Sunshine saw the sincerity and enthusiasm of Circular, and thus trustful relationships were gradually created. Trust then serves as a social coordination scheme that provides positive foundations for reducing risks and building a relationship that in the end will enhance the relational rent of the STP. It is worth noting that, contrary to most business experiences or research suggesting that doing business in China has to be based on existing 'guanxi', Circular 'cold-called' Sunshine to initiate the STP, i.e. Circular made overtures without having any existing contacts at Sunshine. It was the innovation capability, reputation and sincerity of Circular that opened the door for such an opportunity.

\subsubsection{Resource commitment}

'Commitment' concerns a partner's intention and willingness to continue a partnership (Cullen et al., 2000; Isobe et al., 2000), which is always demonstrated by allocating strategic resources to the partnership. Generally speaking, there are three types of resources to be committed to an STP: financial, knowledge and human resources. Pooling supplementary and complementary strategic resources together can integrate the two firms' competences and facilitate innovation due to synergistic effects.

In addition, we can assume that the more a firm invests in terms of physical, financial and human resources, the less likely it is to behave opportunistically, since it is afraid of the termination of the partnership. Thus, it is more likely that each partner will support an open knowledge-sharing environment and that relational rent will be co-created and appropriated. Thus, this case proves the proposition that the level of the partnering firms' commitment to investing in strategic resources is positively related to the performance of an STP (Das and Teng, 2000; Isobe et al., 2000). In addition, the case further specifies that resource commitment acts as an economic coordination mode that not only binds member firms together within an STP to generate relational rent, but also provides future possibilities for sustaining a partnership and relational competitive advantage. 


\subsubsection{Effective coordination}

When facing an open knowledge-sharing environment, firms are presented with opportunities to access and internalise a partner's knowledge resources. This may sometimes lead to a learning race between firms (Hamel, 1991), in which member firms focus too much on capturing each other's critical knowledge resources rather than on jointly creating relational rent. Such alliance rivalry may erode the basis of an STP. In order to ensure knowledge creation while avoiding learning races, effective coordination is needed.

We propose that, owing to the existence of many organisational differences between firms, an eclectic solution should be decided upon in order to make the partnership feasible and reduce potential conflicts. As illustrated by the case, an eclectic solution means coordination which coordination avoids harming either firm's existing working style and evaluation system, and can better orient coordination around the delivery of important, but not necessarily well-specified tasks for each party.

A contract binds member firms to carry out actions needed to jointly achieve the mutual objectives, ensures collaboration rules are established and clarifies responsibilities and benefits, and can be seen as a legal coordination mechanism. Yet, making a contract is usually more challenging between companies with different backgrounds (Blomqvist et al., 2005; Zhou et al., 2008), e.g. in the case of an international STP. Moreover, since a contract is usually signed at the beginning of a partnership, and thus can hardly predict or define companies' behaviour in a very detailed way, it may be less helpful in terms of avoiding learning races.

This case shows how trust as a coordination mechanism complements a contract. A trustful relationship played a role in enhancing the partnering firms' willingness to disseminate each other's knowledge, while during the process of knowledge dissemination, both firms saw each other's competences and had good faith in this STP, which further enhanced mutual trust. In addition, in trustful relationships, firms are less likely to act opportunistically, which may mitigate possible learning races and facilitate relational rent generation. Therefore, as an inimitable and idiosyncratic coordination mechanism, trust may not only significantly reduce the costs of managing the partnership [such as the re-contracting cost and monitoring costs, as suggested in existing literature (Blomqvist et al., 2005; Cullen et al., 2000)], but also complement contracts to avoid learning races, as illustrated by the case.

\subsubsection{Knowledge creation}

Knowledge creation is a major part of innovation and relational rent generation. Existing literature suggests that an open knowledge-sharing routine will create an overlapping knowledge base for the STP and will lead to relational rent creation (Dyer and Singh, 1998). Yet a knowledge-sharing routine does not necessarily result in the generation of relational rent and relational competitive advantage, especially for a firm facing a new foreign partner that differs from it in many ways (as was the case for Sunshine). It is possible that, on occasion, Circular's communications may not be transmitted effectively to or understood by Sunshine unless Sunshine has compatible dissemination capabilities and absorptive capacities. Successful dissemination requires significant knowledge flow to ensure the shared knowledge reaches the relevant people (Chou et al., 2007; Liao et al., 2003), while with absorptive capacity, members' critical knowledge resources 
related to the project can be identified, understood and recombined, and thus new specialised knowledge is co-created (Cohen and Levinthal, 1990), i.e. relational rent generation.

Yet, dissemination capability and absorptive capacity are not just static prerequisites for an STP. The case also shows how Circular and Sunshine's dissemination capabilities and absorptive capacities were gradually developed in mutual learning. As the R\&D process required the partnering firms' understanding of how to integrate knowledge of pump and of solar equipment, much effort was invested into disseminating and explaining knowledge to the partner. During the communication process, both firms' dissemination capabilities were therefore trained and improved, and the enhanced dissemination capabilities further facilitated the improvement of absorptive capacity. Sunshine is now more confident in understanding foreign companies' working styles, while Circular's ability to understand the Chinese business culture and identify new business opportunities has also been improved.

\subsection{Relational rent appropriation}

As shown in this study, relational rent appropriation can be divided into tangible and intangible rent appropriation (see Table 3). Generally speaking, tangible rent refers to newly developed products, revenue and codified knowledge, which are measurable. Intangible rent is newly created knowledge, technological and managerial knowledge spillover, and improved market stance, such as increase of brand awareness.

Table 3 Key issues and tasks of relational rent appropriation: illustrative quotes

\begin{tabular}{|c|c|c|}
\hline Stage & Key issues & Tasks and illustrative quotes \\
\hline \multirow{10}{*}{$\begin{array}{l}\text { Relational rent } \\
\text { appropriation }\end{array}$} & \multirow{10}{*}{$\begin{array}{l}\text { Tangible rent } \\
\text { appropriation }\end{array}$} & $\begin{array}{l}\text { Integration of legal, economic and social modes of coordination } \\
\text { to ensure tangible rent appropriation }\end{array}$ \\
\hline & & - Contract \\
\hline & & $\begin{array}{l}\text { "According to the agreement, the product is owned by } \\
\text { Sunshine, and Circular gets commissions." }\end{array}$ \\
\hline & & $\begin{array}{l}\text { "As we agreed Sunshine's sales networks and after sales } \\
\text { services will be used." }\end{array}$ \\
\hline & & - Resource commitment \\
\hline & & $\begin{array}{l}\text { "The lab is there, and we invested a lot...we look } \\
\text { forward to the future." }\end{array}$ \\
\hline & & $\begin{array}{l}\text { - Trust: Open discussion, mutual understanding, working } \\
\text { together on marketing }\end{array}$ \\
\hline & & $\begin{array}{l}\text { "Though Circular's brand name is not shown at the } \\
\text { product appearance, we still trust each other." " }\end{array}$ \\
\hline & & "This is based on trust and we understand each other." \\
\hline & & $\begin{array}{l}\text { "Though it should be Sunshine in charge of the marketing } \\
\text { since the final system is owned by Sunshine, we helped } \\
\text { with marketing as well. For example, we try to contact } \\
\text { some people. Also, in our Circular concept store in } \\
\text { Shanghai, the solar system is there, even though } \\
\text { Circular's name is not directly shown. This means that } \\
\text { we regard this partnership and project as highly important } \\
\text { to us as well." }\end{array}$ \\
\hline
\end{tabular}


Table 3 Key issues and tasks of relational rent appropriation: illustrative quotes (continued)

\begin{tabular}{|c|c|c|c|}
\hline Stage & Key issues & & Tasks and illustrative quotes \\
\hline \multirow{8}{*}{$\begin{array}{l}\text { Relational rent } \\
\text { appropriation }\end{array}$} & \multirow{8}{*}{$\begin{array}{l}\text { Intangible rent } \\
\text { appropriation }\end{array}$} & 1 & Brand image and strategic position improvements \\
\hline & & \multirow{7}{*}{2} & $\begin{array}{l}\text { "That has been turned upside down now; everyone in the } \\
\text { solar thermal industry wants to talk to us now ..." }\end{array}$ \\
\hline & & & $\begin{array}{l}\text { "In the Chinese solar industry, this is something new } \\
\text { we do, I mean to co-develop a product with a famous } \\
\text { European company... this will set a model to our peers." }\end{array}$ \\
\hline & & & $\begin{array}{l}\text { Gaining knowledge and experiences based on } \\
\text { dissemination capabilities and absorptive capacity }\end{array}$ \\
\hline & & & $\begin{array}{l}\text { "This R\&D project is a milestone in the history of solar } \\
\text { collaboration between Europe and China. It's a big step." }\end{array}$ \\
\hline & & & $\begin{array}{l}\text { "We learnt many managerial knowledge and from Circular. } \\
\text { Also, we get to know the leading standards of R\&D. } \\
\text { To be honest, their employees are more educated and } \\
\text { more familiar with the international standard." }\end{array}$ \\
\hline & & & $\begin{array}{l}\text { "Our market share for solar thermal business is almost } 0 \text { in } \\
\text { OEM way before this project, but now it increased a lot ... } \\
\text { The project helped Circular to be in the solar thermal } \\
\text { market and win the market share faster..." }\end{array}$ \\
\hline & & & $\begin{array}{l}\text { "If you see what we gain from this strategic partnership, } \\
\text { I would say it is a successful partnership." }\end{array}$ \\
\hline
\end{tabular}

As shown in Table 3, in order to ensure that each firm receives proportional benefits from the STP, the integration of different coordination modes is needed. Carefully designed contracts can reduce conflicts and ensure the distribution of relational rent, especially tangible economic benefits. In addition, in this particular case study, invested strategic resources, such as a jointly developed research laboratory and knowledge resources, show the firms' intention of future collaboration, and, with this in mind, they are willing to ensure mutual benefits. This also partly explains why Circular dedicated a sizeable effort to marketing. Based on trustful relationships, member firms tend to believe and understand that the final decision on rent distribution is the optimal choice for the partnership and future collaboration, as illustrated by the branding decision in the case information.

Regarding intangible knowledge rent, it is not the case that only firms with a higher level of absorptive capacity can benefit more from an STP, as suggested by existing literature (Lin et al., 2012); we propose that a focal firm's dissemination capacity determines how many knowledge resources and how much spillover knowledge can be acquired by its partner. This means that dissemination capability is essential to both relational rent generation, as discussed above, and relational rent appropriation. In addition, existing literature suggests that the more salient the focal firm's opportunistic behaviour is, the more relational rent, especially unintended intangible rent such as spillover knowledge (Box D in Figure 1), it may acquire from a partnership (Cohen and Levinthal, 1990; Lavie, 2006).

Yet, based on our findings, we argue that opportunistic behaviour may not benefit the focal firm; rather it may sour the trustful relationship and thus impact knowledge dissemination and sharing. After all, knowledge, especially know-how from the partner, is not easy to absorb, especially in a non-existent knowledge-sharing environment ruined by opportunistic behaviours. Moreover, in order to generate and appropriate relational 
rent, a firm's absorptive capacity may need to be improved to understand its partner, as may be the situation when two partnering firms are different in many ways and are facing innovation potential, as illustrated in the case. Therefore, a mutual learning environment within a trustful relationship is extremely important.

Readers may suggest that this case is just a lucky story in which even minor opportunistic behaviours did not appear, i.e. there were no learning races to appropriate the other's key knowledge resources. But we argue that this is no coincidence. In addition to effective coordination that integrated trust, resource commitment and contract, fit between the two firms played an important role in reducing the likelihood of learning races. Strategic fit in terms of focusing on their own specialised areas made it difficult for the two companies to acquire and understand the key knowledge of the other, especially know-how and tacit knowledge from another industry. Business model fit and the nature of the project, i.e. Circular as an OEM supplier to Sunshine, determined that the knowledge sharing on solar and pump industries remained on the conceptual level. This means that the two firms did not need to understand their partner's key processes and technologies to finish their own tasks; therefore, not much know-how knowledge needed to be shared. This point enriches the existing literature by providing insight into managing the extent of knowledge sharing and how to avoid learning races in an STP.

\subsection{A conceptual framework}

To find the mechanism that eventually produces competitive advantage, i.e. to answer the second research question, we propose a systematic framework for relational competitive advantage in this section. Key factors discussed in Sections 5.2 and 5.3 can be grouped into three categories: process, organisational alliance factors and coordination modes (see Figure 2).

Figure 2 Conceptual framework of relational competitive advantage

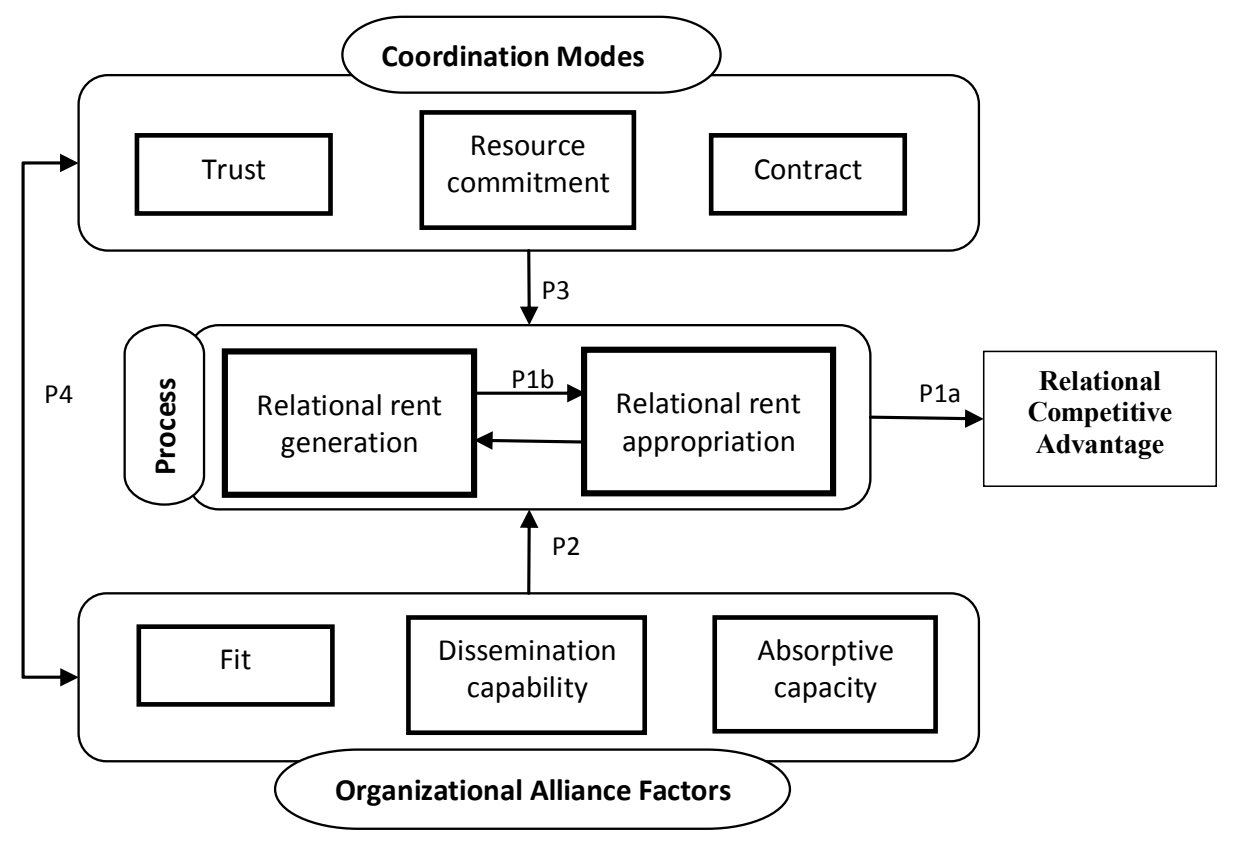


The process of gaining relational competitive advantage consists of relational rent generation and appropriation. In our case analysis, we discovered a recursive, rather than linear, relationship between the generation and appropriation of relational rent within an STP. Once relational rent is generated, partnering firms are able to appropriate them, especially intangible rent. On the other hand, appropriated relational rent, especially newly co-created knowledge, may lay the foundations for future rent generation and deepen the cooperative relationship in the long run. Therefore, unlike existing studies, which tend to separate relational rent generation and appropriation and propose influential factors for each stage, we make the following propositions.

Proposition 1a: The generation of relational competitive advantage requires the completion and success of both relational rent generation and relational rent appropriation.

Proposition 1b: There is a recursive relationship between the generation and appropriation of relational rent.

From the case study, we can see that many concepts come into play, and the complex systematic relationships between these concepts affect both the generation and appropriation of relational rent. This contradicts existing studies, which treat the two stages and their influential factors separately.

There are three organisational alliance factors (fit, absorptive capacity and dissemination capability) that influence the process of an STP. Fit between partners can be both a precondition that determines the potential for establishing an STP and a factor that impacts relational rent generation and appropriation during the collaboration. Significant asymmetry between member firms in terms of resource endowment, strategy, business model and organisational features may cause conflicts and increasing costs during the collaboration, which may reduce the possibilities for relational rent generation and thus influence what can be appropriated from the partnership.

Since the objective of an STP is R\&D and creating new knowledge resources, both dissemination capabilities and absorptive capacity are needed in order to, firstly, share and transfer know-how to partners, secondly, recognise and assimilate the partner's know-how knowledge and, thirdly, co-create the new knowledge resources. On the other hand, absorptive capacity determines how much intangible relational rent, such as knowledge spillover, will be captured by member firms. However, relational rent appropriation will be harmed by fewer captured relational rent and more counter-party appropriating. As a result, member firms need to show their willingness to disseminate knowledge resources to each other.

Based on the above discussion, we hereby propose the following:

Proposition 2: Fit between partners, dissemination capability and absorptive capacity are positively related to relational rent generation and relational rent appropriation.

Every STP faces the risks of unsatisfactory cooperation and underperformance, so in order to ensure the performance of an STP, different coordination modes are needed. In this case, we see three coordination modes: trust, resource commitment and contract. Trust is a social coordination mode, while resource commitment is an economic coordination mode that binds partners together. A contract is a legal coordination mode that is most effective when combined with other soft coordination modes such as trust and resource commitment. Therefore, we propose: 
Proposition 3: The greater the volume of resources committed by each member, the more detailed the content of the contract outlining members' responsibilities and mutual benefits; and the greater the degree of trust between members, the more relational rent will be generated, and the more likely relational rent appropriation will be ensured.

Moreover, organisational factors and coordination modes mutually enhance each other. A firm that is regarded as having a strong absorptive capacity and dissemination capability will be regarded as a well-qualified and professional partner by its counterparties, thereby enhancing trust between member firms. On the other hand, a trustful relationship and invested strategic resources will increase the extent of compatibility of member firms, since both will be more willing to search for a mutual fit. Trust and committed knowledge resources may also improve a firm's absorptive capacity by providing an environment of mutual learning and collaborative learning through the STP. The contract is mainly designed to prevent severe learning races, and since member firms' behaviours are regulated according to the contract, their absorptive capacity, dissemination capability and the extent of fit are enhanced as well. Thus, we hereby propose:

Proposition 4: The three coordination modes, i.e. trust, resource commitment and contract, are mutually reinforced by fit between member firms, dissemination capability and absorptive capacity.

\section{Conclusion}

By incorporating a case study of an STP between Danish and Chinese firms, this paper investigates how companies gain relational competitive advantages from STPs during the process of relational rent generation and appropriation. Rather than treating relational rent generation and appropriation as separate stages, we argue that there are recursive relationships between the two stages. Only when both the generation and the appropriation of relational rent are successfully realised can an STP contribute to relational competitive advantage. The organisational alliance factors (fit, absorptive capacity and dissemination capabilities) and coordination modes (trust, resource commitment and contract) found in the study are positively related to both relational rent generation and appropriation, simultaneously.

Though individual factors within our final framework are informed by existing theories and literature, the main contribution of the study is identifying, enriching and integrating these factors, and understanding the creation of relational competitive advantage by STPs as a systematic mechanism, a lesson academia has largely ignored. In this sense, this study also provides the possibility of linking literature on partner selection, knowledge management and alliance management. Furthermore, the concept of relational rent, which is ambiguously defined in the existing literature, is specified and enriched in the context of an STP.

The study also conveys some practical insights for initiating and managing STPs between TNCs and Chinese local firms. Regarding initiating an STP with a Chinese partner, this study indicates that identifying a potential Chinese partner largely focused on its own specialised area will partly reduce potential opportunistic behaviours such as copying even before the formation of a partnership. Also, this study provides insights on how to start an STP related to key knowledge resources without having pre-existing 'guanxi' in the Chinese business context. 
This study is an explorative case study that provides new insights into existing theories of relational competitive advantages. Unlike quantitative studies that can be generalised to populations statistically, case studies can only provide an analytical generation (Yin, 2008), which means that case studies are generalised to theoretical propositions, as was done in this study. Readers may also question whether this single case is able to provide analytical generation and whether it is a unique case from a unique context. The STP between Sunshine and Circular itself is an idiosyncratic cross-industrial collaboration that would be difficult for another company to imitate precisely. However, it is also a typical case showing the $R \& D$ collaboration between a Chinese company and a TNC. Thus, it is not an exceptional case for TNC subsidiaries in China or other developing countries. Moreover, China shares many important characteristics with other emerging economies, making propositions drawn from this case relevant to many others. However, the current study is not sufficient to close this area to further research. For example, an interesting future research topic would be investigating how to balance the three coordination modes, i.e. contract, trust and resource commitment, within different contexts. Also, the proposed framework needs to be corroborated by future empirical research.

\section{Acknowledgements}

We acknowledge the anonymous reviewers. The research is partially funded by NSF of China (Project No. 71273152). We thank Tsinghua University for providing financial support for the research. The Sino-Danish Centre for Education and Research is also greatly appreciated.

\section{References}

Barney, J. (1991) 'Firm resources and sustained competitive advantage', Journal of management, Vol. 17, No. 1, pp.99-120.

Blomqvist, K., Hurmelinna, P. and Seppänen, R. (2005) 'Playing the collaboration game right: balancing trust and contracting', Technovation, Vol. 25, pp.497-504.

Cantwell, J. and Janne, O. (1999) 'Technological globalisation and innovative centres: the role of corporate technological leadership and locational hierarchy', Research Policy, Vol. 28, No. 3, pp.119-144.

Capaldo, A. and Petruzzelli, A.M. (2011) 'In search of alliance-level relational capabilities: balancing innovation value creation and appropriability in R\&D alliances', Scandinavian Journal of Management, Vol. 27, No. 3, pp.273-286.

Chou, T., Chang, P., Cheng, Y. and Tsai, C. (2007) 'A path model linking organizational knowledge attributes, information processing capabilities, and perceived usability', Information \& Management, Vol. 44, pp.408-417.

Cohen, W. and Levinthal, D. (1990) 'Absorptive capacity: a new perspective on learning and innovation', Administrative Science Quarterly, Vol. 35, pp.128-152.

Cullen, J.B., Johnson, J.L. and Sakano, T. (2000) 'Success through commitment and trust: the soft side of strategic alliance management', Journal of World Business, Vol. 35, No. 3, pp. $223-240$.

Das, T.K. and Teng, B-S. (2000) 'A resource-based theory of strategic alliance', Journal of Management, Vol. 26, No. 1, pp.31-61. 
Datta, D.K. (1991) 'Organizational fit and acquisition performance: effects of post-acquisition integration', Strategic Management Journal, Vol. 12, No. 4, pp.281-297.

Douma, M.U., Bilderbeek, J., Idenburg, P.J. and Looise, J.K. (2000) 'Strategic alliances: managing the dynamics of fit', Long Range Planning, Vol. 33, pp.579-598.

Durant, R., Bruyaka, O. and Mangematin, V. (2008) 'Do science and money go together? The case of French biotech industry', Strategic Management Journal, Vol. 29, No. 12, pp.1281-1299.

Duschek, S. (2004) 'Inter-firm resources and sustained competitive advantage', Management Revue, Vol. 15, No. 1, pp.53-73.

Duysters, G., Kok, G. and Vaandrager, M. (1999) 'Crafting successful strategic technology partnerships', R\&D Management, No. 4, pp.343-351.

Dyer, J.H. and Singh, H. (1998) 'The relational view: cooperative strategic and sources of interorganizational competitive advantage', Academy of Management Review, Vol. 23, No. 4, pp.660-679.

Dyer, J.H., Kale, P. and Singh, H. (2001) 'How to make strategic alliances work', MIT Sloan Management Review, Vol. 42, pp.37-43.

Dyer, J.H., Singh, H. and Kale, P. (2008) 'Splitting the pie: rent distribution in alliances and networks', Management and Decision Economics, Vol. 29, pp.137-148.

Dyer, W.G. and Wilkins, A.L. (1991) 'Better stories, not better constructs, to generate better theory: a rejoinder to Eisenhardt', Academy of Management Review, Vol. 16, No. 3, pp.613-619.

Eisenhardt, K.M. (1989) 'Building theories from case study research', Academy of Management Review, Vol. 14, No. 4, pp.532-550.

Eisenhardt, K.M. and Graebner, M.E. (2007) 'Theory building from cases: opportunities and challenges', Academy of Management Journal, Vol. 50, No. 1, pp.25-32.

Glaser, B.G. and Strauss, A.L (1967) The Discovery of Grounded Theory: Strategies for Qualitative Research, Aldine, Chicago, IL.

Gomes-Casseres, B. (2003) 'Competitive advantage in alliance constellations', Strategic Organization, Vol. 1, No. 3, pp.327-335.

Hagedoorn, J. (1993) 'Understanding the rationale of strategic technology partnering: interorganizational modes of cooperation and sectoral differences', Strategic Management Journal, Vol. 14, pp.371-385.

Hagedoorn, J. (2002) 'Inter-firm R\&D partnerships: an overview of major trends and patterns since 1960', Research Policy, Vol. 31, pp.477-492.

Hagedoorn, J. and Narula, R. (1996) 'Choosing organizational modes of strategic technology partnering: international and sectoral differences', Journal of International Business Studies, Vol. 27, pp.265-284.

Håkansson, H. and Snehota, I. (1989) 'No business is an island: the network concept of business strategy', Scandinavian Journal of Management, Vol. 5, No. 3, pp.187-200.

Hamel, G. (1991) 'Competitive for competence and inter-partner learning within international strategic alliances', Strategic Management Journal, Vol. 12, pp.83-103.

Ireland, R.D., Hitt, M.A. and Vaidyanath, D. (2002) 'Alliance management as a source of competitive advantage', Journal of Management, Vol. 28, No. 3, pp.413-446.

Isobe, T., Makino, S. and Montgomery, D.B. (2000) 'Resource commitment, entry timing, and market performance of foreign direct investments in emerging economies: the case of Japanese international joint ventures in China', Academy of Management Journal, Vol. 43, No. 3, pp.468-484.

Jarillo, J.C. (1988) ‘On strategic networks', Strategic Management Journal, Vol. 9, pp.31-41.

Kale, P. and Singh, H. (2009) 'Managing strategic alliances: what do we know now, and where do we go from here?' Academy of Management Perspectives, Vol. 23, pp.45-62.

Lavie, D. (2006) 'The competitive advantage of interconnected firms: an extension of the resourcebased view', Academy of Management Review, Vol. 31, No. 3, pp.638-658. 
Liao, J., Welsch, H. and Stoica, M. (2003) 'Organizational absorptive capacity and responsiveness: an empirical investigation of growth-oriented SMEs', Entrepreneurship Theory and Practice, Vol. 28, No. 1, pp.63-85.

Lin, C., Wu, Y.J., Chang, C., Wang, W. and Lee, C.Y. (2012) 'The alliance innovation performance of R\&D alliances: the absorptive capacity perspective', Technovation, Vol. 32, pp.282-292.

McCutchen, W.W., Swamidass, P.M. and Teng, B. (2008) 'Strategic alliance termination and performance: the role of task complexity, nationality, and experience', Journal of High Technology Management Research, Vol. 18, pp.191-202.

Miles, M.B. and Huberman, A.M. (1994) Qualitative Data Analysis: An Extended Source Book, Sage, Thousand Oaks, CA.

Mursitama, T.N. (2006) 'Creating relational rents: the effect of business groups on affiliated firms' performance in Indonesia', Asia Pacific Journal of Management, Vol. 23, pp.537-557.

Park, S.H. and Ungson, G.R. (1997) 'The effect of national culture organizational complementarity, and economic motivation on joint venture dissolution', Academy of Management, Vol. 40, No. 2, pp.279-307.

Narula, R. and Hagedoorn, J. (1999) 'Innovating through strategic alliances: moving towards international partnerships and contractual agreements', Technovation, Vol. 19, pp.283-294.

Peteraf, M.A. (1993) 'The cornerstones of competitive advantage: a resource-based view', Strategic Management Journal, Vol. 14, No. 3, pp.179-191.

Siggelkow, N. (2007) 'Persuasion with case studies', Academy of Management Journal, Vol. 50, No. 1, pp.20-24.

von Zedtwitz, M. (2004) 'Managing foreign laboratories in China', $R \& D$ Management, Vol. 34, No. 4, pp.439-452.

$\mathrm{Wu}, \mathrm{J}$. (2012) 'Technological collaboration in product innovation: the role of market competition and sectoral technological intensity', Research Policy, Vol. 41, No. 2, pp.489-496.

Yasuda, H. (2005) 'Formation of strategic alliances in high-technology industries: comparative study of the resource-based theory and the transaction-cost theory', Technovation, Vol. 25, pp.763-770.

Yin, R.K. (2008) Case Study Research: Design and Methods, 4th ed., Sage, Thousand Oaks, CA.

Zhang, J., Baden-Fuller, C. and Mangematin, V. (2007) 'Technological knowledge base, R\&D organization structure and alliance formation: evidence from the biopharmaceutical industry', Research Policy, Vol. 36, No. 4, pp.515-528.

Zhou, K.Z., Poppo, L. and Yang, Z. (2008) 'Relational ties or customized contracts? An examination of alternative governance choices in China', Journal of International Business Studies, Vol. 39, pp.526-534.

\section{Note}

1 For confidentiality considerations, company names are pseudonyms. 